原

胃癌患者に打ける非特異的免疫能に関する臨床的研究

ーリンパ球幼若化反応の評価と意義一

日本医科大学第 2 外科教室（指導：主任教授：庄司

佑)

小川泰史

\title{
CLINICAL STUDY OF NONSPECIFIC IMMUNE RESPONCE IN PATIENTS WITH GASTRIC CANCER
}

-EVALUATION AND SIGNIFICANCE OF LYMPHOCYTIC BLASTOGENESIS-

Yasushi OGAWA

Second Department of Surgery, Nippon Medical School, Tokyo

(Director: Chief Prof. Tasuku SHOJI, M.D.)

術前未治療時における胃癌患者260例と非癌患者112例の非特異的免疫能をリンバ球幼 若化反応を中心に, 各パラメータの年龄, 血清アルブミン值との相関, 癌の進行程度と の関保, さらに年龄別 (60歳以上, 未满群), 血清アルブミン值別 $(4.0 \mathrm{~g} / \mathrm{d} l$ 以上, 未满 群),および組織学的分化度別 (分化型, 低分化型) の変動をしらべ, 各ハラメータの有 用性と意義について検討した。

年齢との関係では, ConA > PHA >リンバ球比>リンパ球数の順で負の相関がみられ た. 2 群別の検討では, PHA とConA が60歳以上群で有意の低值を示した.

血清アルプミン値との関係では, Con $\mathrm{A}>\mathrm{T}$ 細胞比>リンバ球比の順で正の相関がみ られた. 2 群別の検討では, リンバ球比のみが $4.0 \mathrm{~g} / \mathrm{dl}$ 末満群で有意の低值を示した. 又, $4.0 \mathrm{~g} / \mathrm{dl}$ 末满群で PHA, ConA, リンハi球比の stage による変動が消失し，特に $4.0 \mathrm{~g} / \mathrm{dl}$ 未満における stage I での免疫能の低下が示唆された。

癌進行程度との関保で一定の傾向を示したのは, PHA, ConA, ConA/PHA, リンパ 球比,リンバ球数であったが, バラメータとしての有用性に沶いて優れていたのは PHA とリンハ球比であった. 特に, 早期癌, 進行癌, 末期癌の判別や治复切除が可能か否か の判断に有用な指標になると思われた. ConA/PHA は癌の進行と共に漸増㑯向を示す が，そのピークは岈除可能な stage IVにあると思われた. 又, ConA/PHAミ1.0を示す 症例の71\%が stage IV であった。

組織学的分化度別の検討では, PHA, ConA の分化型, 低分化型における stage 別の変 動に相连がみられ，共に分化型でより良い:ラメータとなると思われた。. 特に stage III, IVでの両群間の差は大きく, 分化型の stage III, IVにおける免疫能の低下が示唆され, 免废賦活剂の適応を考えるらえにす，これらを分けて検討する必要があると思われた，

柬引用語：胃癌, リンバ球幼若化反応, 胃癌組織学的分化度

\section{I. 綪 言}

担癌宿主の免疫能と発癌および癌の進展とのかかわ りあいについて，多くの研究がなされ，その実体は次 第に解明されつつある。しかし，その多くは試験管内
又は実験動物でなされており，人癌，特に臨床面にお いてははとんぞ解明されていないのが現状である。人 癌では自然発生癌の抗原性はあってる覀めて弱く，そ の発生時期をとらえる事は不可能に近い，又, 担癌状 
態を修飾する種々の背景因子に加え免疫機構の複雑さ るその解明をより困難なるのにしている。

現在, 免疫能に関する研究は, 特異的免疫能と非特 異的免疫能に大別する事が出来る. 前者は癌の特異抗 原ししは腫湯関連抗原に関するものでモノクロナー ル抗体の導入により，診断，治療面への応用が各方面 で研究されている，癌に対する特異的猃断，治療への 可能性は，まさにこの分野に含まれているのであるか， その研究はようやく緒についたばかりで臨床への応用 には，まだかなりの時間を要すると思われる，後者の 非特異的免度能に関寸る研究は，各種免疫賦活浏の臨 床応用をはじめ, 診断面に颃いても広く普及してきて いる. しかし，非特異的免疫能は，その名の示寸如く 特異性に乏しく生体の様々な因子により影鿾をらけ正 確な担癌状態を反映しているとはいえない，現在用い られている各種バラィータがどのよ5な因子に影響さ れ，その変動がどのよらな意味をすつのか、統一した 結論は出されておらず，これらの数值を正確に評価す る事さえ難しいのが現状である。

今回，一般的な非特異的免疫能の検查法として評価 されている mitogen PHA, ConA, PWMによるリン 八球幼若化反応（以下 PHA, ConA, PWM) と末梢血 のリンパ球比, リンパ球数， $\mathrm{T}$ 細胞比， B 細胞比につ いて, 術前末治療時の胃癌患者260例で測定し, 手術所 見および組織学的所見と retrospective に比較検討し た。さらに背景因子として年龄および血清フルブミン 值 (以下アルブミン値) との相関, 年齢別 (60歳以上, 末满), フルプミン值別 $(4.0 \mathrm{~g} / \mathrm{d} 1$ 以上, 未満), 組織学 的分化度別（分化型，低分化型）の検討を加え，これ らパラメータの有用性と評価について文献的考察をる 加え報告する。

\section{1. 研究対象}

\section{II. 研究対象およひ研究方法}

昭和53年 4 月より昭和58年 4 月までにおいて手術を うけた胃癌患者367例のうち, 術前未治療時に非特異的 免疫能の測定かなされ，かつ㭪後十分な組織学的㭘索 が行なわれた260例と対照群として非癌症例112例の総 計372例を対象とした。

対照群は表 1 の如く, 胃十二指腸潰痚36例, 胆石症

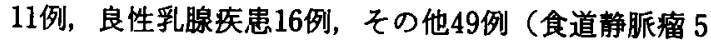
例，胃ボリープ 4 例，脇震胞 4 例等々)の112例である. 白血球数が 10,000 以上の症例を除きすべてを対象とし た. 平均年龄は53.0歳, 平均アルブミン值は $4.16 \mathrm{~g} / \mathrm{dl}$, 平均白血球数は $5,791 / \mathrm{mm}^{3}$ であった（表 1 ）。
表 1 対昭群(非㾔症例群) 各疾患別の症例数と背景 因子

\begin{tabular}{|c|c|c|c|c|}
\hline 疾告名 & 弆 例 & $\begin{array}{c}\text { 平均年令 } \\
\text { (干) }\end{array}$ & 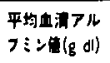 & 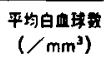 \\
\hline 田·指 & 36 & 53.3 & 3.96 & 6655 \\
\hline 周 石 症 & 11 & 60.9 & 4.08 & 5385 \\
\hline 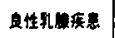 & 16 & 45.0 & 4.72 & 4887 \\
\hline * の他 & 49 & 53.6 & 4.22 & 5456 \\
\hline It (平均) & 112 & 53.0 & 4.16 & 5791 \\
\hline
\end{tabular}

表 2 担㾇群 各ステージの症例数と背景因子

\begin{tabular}{|c|c|c|c|c|}
\hline stage & 促 例 数 & $\begin{array}{c}\text { 平均年令 } \\
\text { (尹) }\end{array}$ & 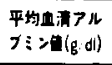 & $\begin{array}{c}\text { 平均白血轮影 } \\
\left(/ \mathrm{mm}^{3}\right)\end{array}$ \\
\hline 1 & 64 & 56.6 & 4.29 & 5370 \\
\hline II & 38 & 63.3 & 3.86 & 5430 \\
\hline III & 68 & 58.6 & 4.12 & 6140 \\
\hline IV & 90 & 59.6 & 3.86 & 6137 \\
\hline 旪（平均） & 260 & 59.6 & 4.03 & 5845 \\
\hline
\end{tabular}

担癌群の各 stage における症例数と背景因子は表 2 の如くであり, stage は胃癌取り扱い規䄪"1の組織学的 進行程度に従い分類した. stage I64例, stage II38例, stage III68例， stage IV90例の總計260例で，やはり白 血球数 10,000 以下を基準とした。平均年龄は59.6歳で 非癌群より若干高く, 平均アルプミン值は $4.03 \mathrm{~g} / \mathrm{dl}$ 之 非癌群よりやや低い傾向がみられた。平均白血球数は $5,845 / \mathrm{mm}^{3}$ で非癌群と差はみられなかった。 stage 間 の比較では, stage II に高龄者が多く、フルブミン值も 低い特徵がみられた（表 2).

\section{2. 研究方法}

(a). 検討項目

対象はすへてて入院と同時にへパリン加末梢血 $15 \mathrm{ml}$ を採取し，PHA，ConA，PWM，T細胞比， B 細胞比 を測定し, 同時に採取した末梢血 $5 \mathrm{ml} に$ に, 白血球数, リンパ球比，アルブミン値を測定した。

(b) 湘定方法

アルブミン值：セルローズフセテート電気泳動法

$\mathrm{T}$ 細胞比；E口ゼット形成法

$B$ 細胞比：蛍光抗体法

PHA, ConA, PWM：H3.サイミシンン取り込み法 
(C) 検討方法および目的

(1) 非癌群に㧍ける各パラメータと年齢怙よびアル ブミン值との相関, 各バラメータ相互の相関をしらへ, 各バラメータがどのような因子に影響をらけるか検討 した。

(2) 担癌群においても同様の桧索を試み, 非癌群と比 較する事により，担癌による影響を検討した，

(3) 各バラメータと癌の進行程度との関係をしらべ, 癌進行程度のパラメータとしての有用性を恰討した。 非特異的免疫能は局所の微小な变化をとらえるには不 適当であると考充，可及的に傾向を判定する分類によ る検討を試みた。

項目は， $\mathrm{H}$ 因子の有無別， $\mathrm{P}$ 因子の有無別， $\mathrm{n}$ 因子の 有無別，ps 因子の有無別，組織学的 stage 分類，予後 の著しく異なる早期癌群, 進行癌群, 切除不能であっ た末期癌群(以下，早期群，進行群，末期群），さらに

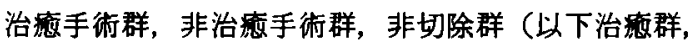
非治疼群, 非切除群)ににわて検討した。

(4) 最後に，今回の 260 例とい5症例数は，その背景 因子により 2 群に分けらる数であると考え，年龄で60 歳以上群と60歳未満群に，アルブミン值で $4.0 \mathrm{~g} / \mathrm{dl}$ 以 上群と $4.0 \mathrm{~g} / \mathrm{dl}$ 未満群に分け，さらに癌の組織学的分 化の程度により分化型 (well, moderately differentiated tubular adenocarcinoma, papillary adenoca.)，低分化型 (poorly diff. adenoca., mucinous adenoca., signet-ring cell ca.) とに分け stage 別に検 討した．年龄とアルブミン値の境界値の設定は難しい が，症例数の少ないデータの信頼度は低いと考えてお ク，2 群に分けるならば，その平均値（年龄では59.6 藏, フルブミン值では $4.03 \mathrm{~g} / \mathrm{dl}$ )で分けるのが適当であ

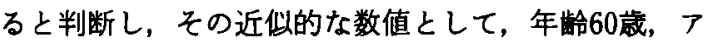
ルブミン值 $4.0 \mathrm{~g} / \mathrm{dl}$ を一応境界值とした。

\section{III. 研究成䋶}

成樍はすべてコンピュータによる統計処理により統 計学的に $5 \%$ 以下の危険率で有意性を示したもののみ を評価した。

1. 非癌群，担癌群に括ける各パラメータと年齢およ びアルブミン值との相関（表 3）

\section{(a) 非癌群}

年齢との相関で正の相関を示したバラメータはな $く$, PHA, ConA, リンパ球比, リンハ球数が負の相関 を示した。相関の強さは, ConA $>$ PHA >リンバ球比> リンバ球数の順であった. アルプミン值との相関では, Con $\mathrm{A}>\mathrm{T}$ 細胞比>リンパ球比の順で正の相関がみら

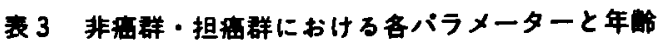
及ひ血清アルフミン值との相閉〔統計学的に $5 \%$ 以 下の危険率で有意の相闺を認めたるののみ上段に相 関係数 $(\gamma)$ ，下段に相関の有意性（p）を示めした。

\begin{tabular}{|c|c|c|c|c|}
\hline & 非 & 群 & 担 & 群 \\
\hline & 年 & ロ淪アルフミン & 年 & 且消フルフラン・ \\
\hline PHA & $\begin{array}{l}\gamma=-0.37 \\
p<0.001\end{array}$ & $(-)$ & $\begin{array}{l}\gamma=-0.171 \\
p=0.006\end{array}$ & $(-)$ \\
\hline ConA & $\begin{array}{l}\gamma=-0.418 \\
p<0.001\end{array}$ & $\begin{array}{l}\gamma=0.339 \\
p=0.003\end{array}$ & $\begin{array}{l}\gamma=-0.333 \\
p<0.001\end{array}$ & $(-)$ \\
\hline PWM & $(-)$ & $(-)$ & $(-)$ & $(-)$ \\
\hline リンハ球比 & $\begin{array}{l}\gamma=-0.314 \\
p<0.001\end{array}$ & $\begin{array}{l}\gamma=0.193 \\
p=0.045\end{array}$ & $(-)$ & $\begin{array}{l}\gamma=0.239 \\
p=0.001\end{array}$ \\
\hline リンバ球政 & $\begin{array}{l}\gamma=-0.216 \\
p=0.015\end{array}$ & $(-)$ & $(-)$ & $(-)$ \\
\hline T稩胞比 & $(-)$ & $\begin{array}{l}\gamma=0.251 \\
p=0.012\end{array}$ & $(-)$ & $(-)$ \\
\hline B晸胞比 & $(-)$ & $(-)$ & $(-)$ & $(-)$ \\
\hline
\end{tabular}

れた。

(b) 担癌群

年龄との相関では，PHA，ConAのみが負の相関を 示し，その強さはConA P PHA であった.アルブミン 值との相関では, リンバ球比のみが正の相関を示した。

(C) 非癌群, 担癌群の比較

統計学的には, 症例数の多い担癌群は相関の有意性 を示しやすいはずであるが，実際には，年齢，フルブ ミン値共に担癌群で相関を示すパラメータの数は减少 した，又，相関保数も担癌群で减少する傾向がみられ た。相関の強さの順序は，年㱓では両群間に相違はみ られないが、フルブミン值では非癌群で強い相関を示 した ConA， $\mathrm{T}$ 細胞比が担癌群では相関を示さず, 両群 間で相違がみられた。

2. 非癌群, 担癌群におけるバラメータ相互の相関 (表 4 )

(a) 非癌群

正の相関を示したグループは, PHA-ConA, ConA. PWM, ConA-リンハ:球比, リンパ球比ーリンハ球数。 リン八球比一 $\mathrm{T}$ 細胞比, リンハ球数一B 細胞比であっ た。負の相関を示したグループは， $\mathrm{T}$ 細胞比一B 細胞 比のみであった。

(b) 担癌群

正の相関を示したクループは，PHA-ConA，PHAPWM, PHA・リンパ球比, PHA-T 細胞比, ConA. PWM, ConA-リンバ球比, ConA-リンバ球数, ConA. $\mathrm{T}$ 細胞比, PWM-T 稩胞比, リンハ球比ーリンハ球数, 
表 4 非藏群（斜線より右上）と担演群（斜線より左下）における各パラメーター相 互の相関〔 $\gamma$ : 相関保数, $\mathrm{p}$ : 相闻の有意性

\begin{tabular}{|c|c|c|c|c|c|c|c|}
\hline & PHA & ConA & PWM & リンハ球比 & リンハ球数 & $T$ 梱比 & B 塯胞比 \\
\hline PHA & & $\begin{array}{l}\gamma=0.715 \\
p<0.001\end{array}$ & $(-)$ & $(-)$ & $(-)$ & $(-)$ & $(-)$ \\
\hline ConA & $\begin{array}{l}\gamma=0.699 \\
p<0.001\end{array}$ & & $\begin{array}{l}\gamma=0.582 \\
p<0.001\end{array}$ & $\begin{array}{l}\gamma=0.259 \\
p=0.019\end{array}$ & $(-)$ & $(-)$ & $(-)$ \\
\hline PWM & $\begin{array}{l}\gamma=0.288 \\
\rho=0.001\end{array}$ & $\begin{array}{l}y=0.439 \\
p<0.001\end{array}$ & & $(-)$ & $(-)$ & $(-)$ & $(-)$ \\
\hline リン八球比 & $\begin{array}{l}\gamma=0.139 \\
p=0.031\end{array}$ & $\begin{array}{l}\gamma=0.193 \\
p=0.003\end{array}$ & $(-)$ & & $\begin{array}{l}\gamma=0.619 \\
D<0.001\end{array}$ & $\begin{array}{l}\gamma=0.287 \\
p=0.004\end{array}$ & $(-)$ \\
\hline リンハ球数 & $(-)$ & $\begin{array}{l}\gamma=0.142 \\
p=0.03\end{array}$ & $(-)$ & $\begin{array}{l}\gamma=0.728 \\
p<0.001\end{array}$ & & $(-)$ & $\begin{array}{l}\gamma=0.223 \\
p=0.026\end{array}$ \\
\hline $\mathrm{T}$ 細胞比 & $\begin{array}{l}\gamma=0.163 \\
p=0.011\end{array}$ & $\begin{array}{l}\gamma=0.141 \\
p=0.03\end{array}$ & $\begin{array}{l}\gamma=0.234 \\
p=0.006\end{array}$ & $\begin{array}{l}\gamma=0.197 \\
p=0.003\end{array}$ & $(-)$ & & $\begin{array}{l}\gamma=-0.748 \\
p<0.001\end{array}$ \\
\hline B嘼胞比 & $(-)$ & $(-)$ & $(-)$ & $(-)$ & $(-)$ & $\begin{array}{l}\gamma=-0.268 \\
p<0.001\end{array}$ & \\
\hline
\end{tabular}

リンパ球比一 $\mathrm{T}$ 細胞比であった。負の相関を示したの は, $\mathrm{T}$ 細胞比一B 細胞比のみであった。

(C) 非癌群, 担癌群の比較

症例数の多い担癌群においてより多くのグループ間 で相関が涊められた事は，前述の統計学的性質之矛盾 せず，多少，相関係数は担癌群で減少する傾向はある が，両群間に著しい差はみられないと思われた。大き く異なる点は, 非癌群でのみ相関を示したリンハ球数.
$\mathrm{B}$ 細胞比と担癌群で著しく相関係数の減少を示した (非癌群 $\gamma=-0.748$, 担癌群 $\gamma=-0.268$ ) $\mathrm{T}$ 細胞比-B 細胞比であった。これらは共に B 細胞比が関与してお り，担癌により B 細胞比と他のバラメータとのバラン スに乱れが生じる可能性が示唆された。

3. 各バラメータと癌進行程度との関係（図1～図 8)

i）癌進行程度の各因子におけるバラメータの变動

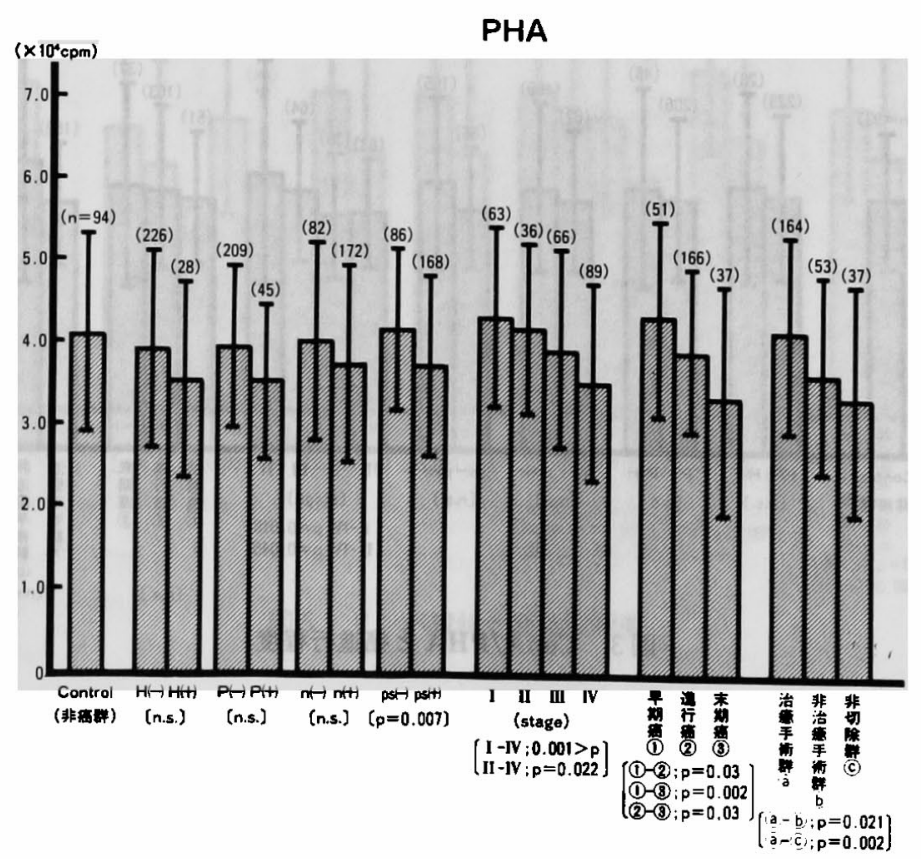

困 1 PHA と我進行程度 
ConA

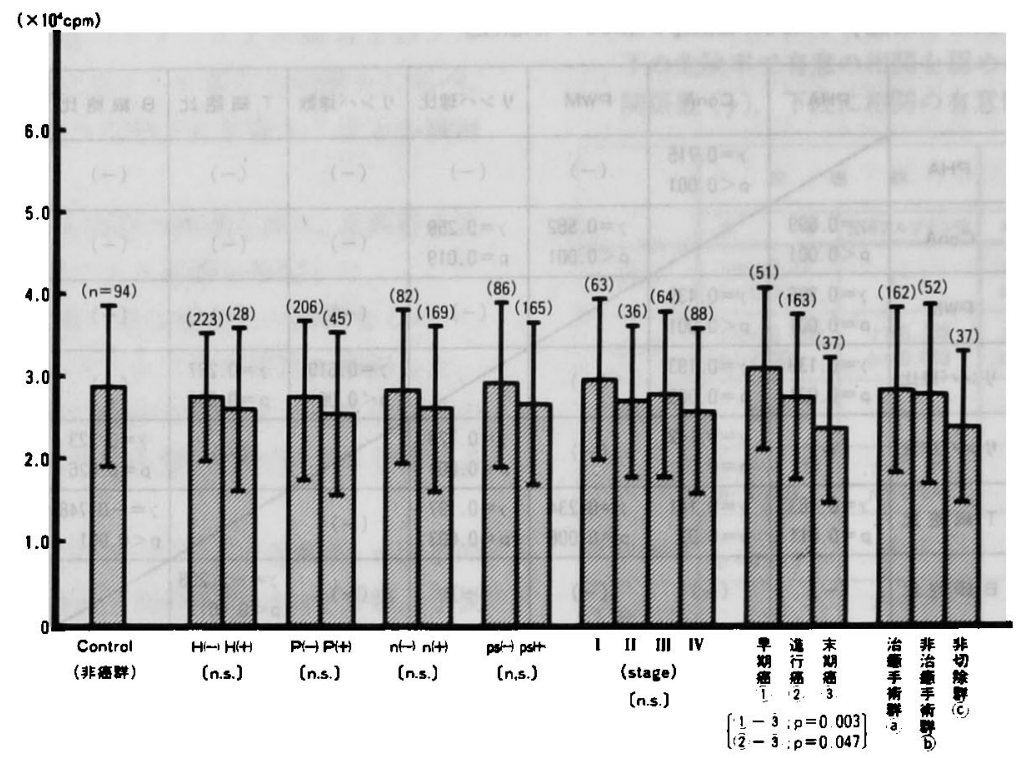

图 $2 \operatorname{Con} \mathrm{A}$ と整進行程度

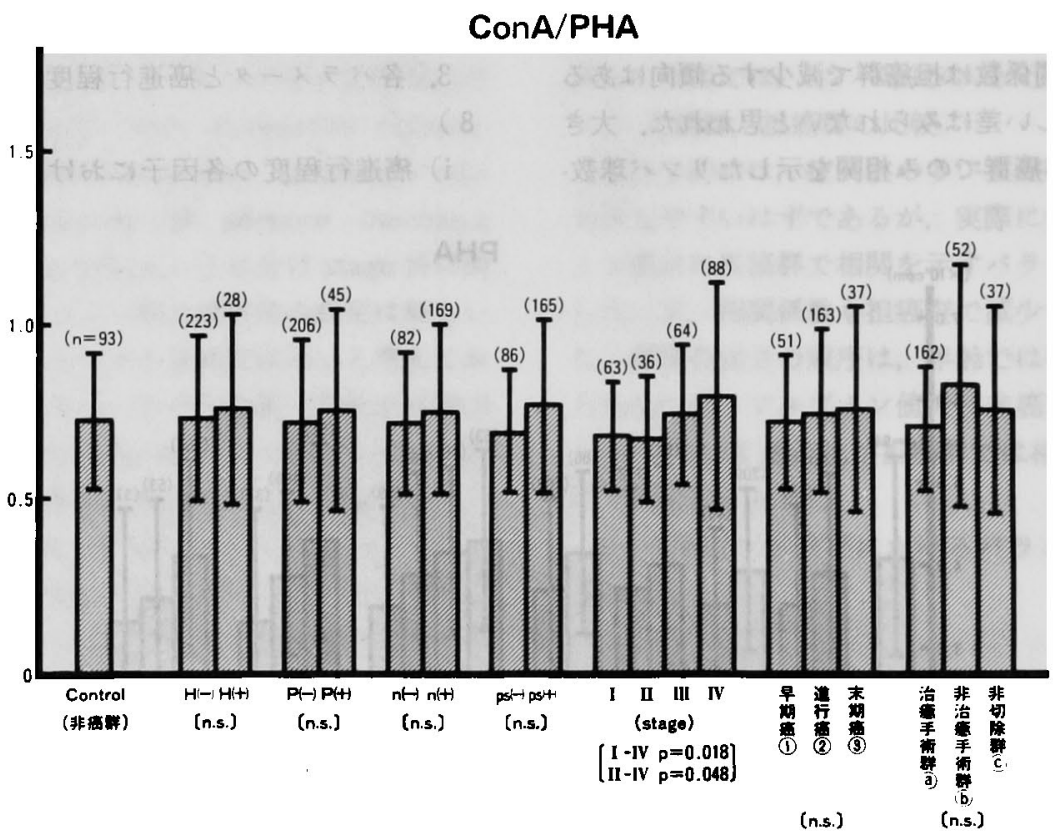

图 3 ConA/PHA と㾖進行程度

\section{と有用性}

(a) PHA (図 1)

PHA は全体として癌の進行に伴い一定した減少傾 向を示し，バラメータとしての有用性は高い。有意差
は, ps $(-)-(+)$ 間, stage I, stage II と stage IV 間, 早期一進行一末期の各群間及び治瘦群と非治海, 非切 除群との間で認められ比較的進行していない時期と強 く進行した時期の判別に有用と思われた。特に，早期 


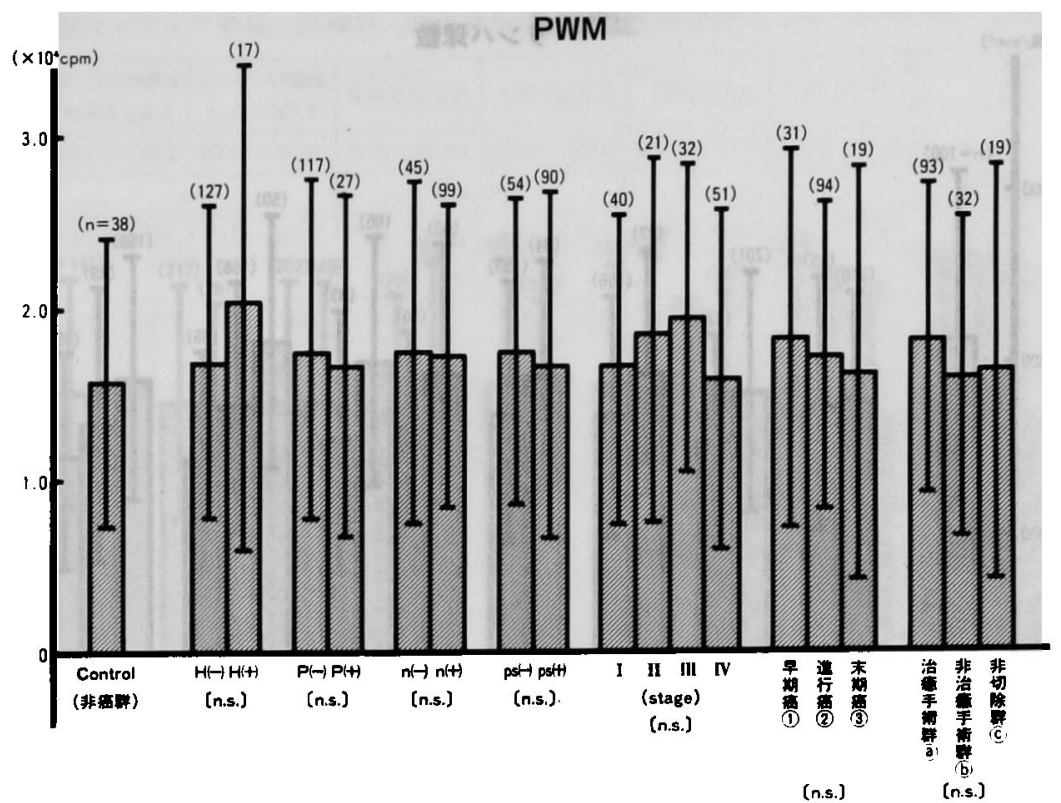

图4 PWM と我進行程度

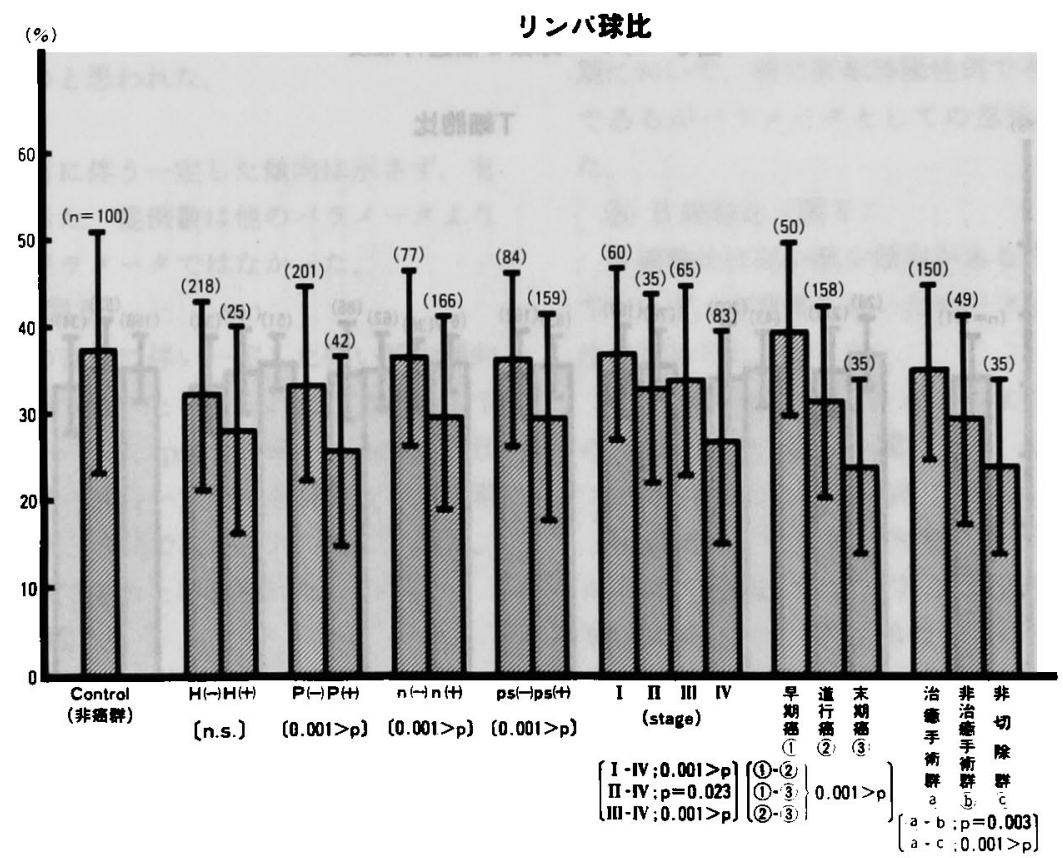

图 5 リンパ球比と雷進行程度

一進行一末期群の判別や治窟切除が可能であるか否か の判定に有用な指標となり

(b) ConA（图 2)

ConA は全体としてみると减少傾向を示すか，その 程度は弱く有用なバラメータとは認められなかった。
有意差も早期, 進行群と末期群間, 治筱群と非切除群 間でみられたにすぎず，末期に至って有意の減少がみ られるのみであった。

(C) 反応性比率 ConA/PHA (図 3)

ConA/PHA は, 癌の進行に伴い弱い增加㑯向を示 


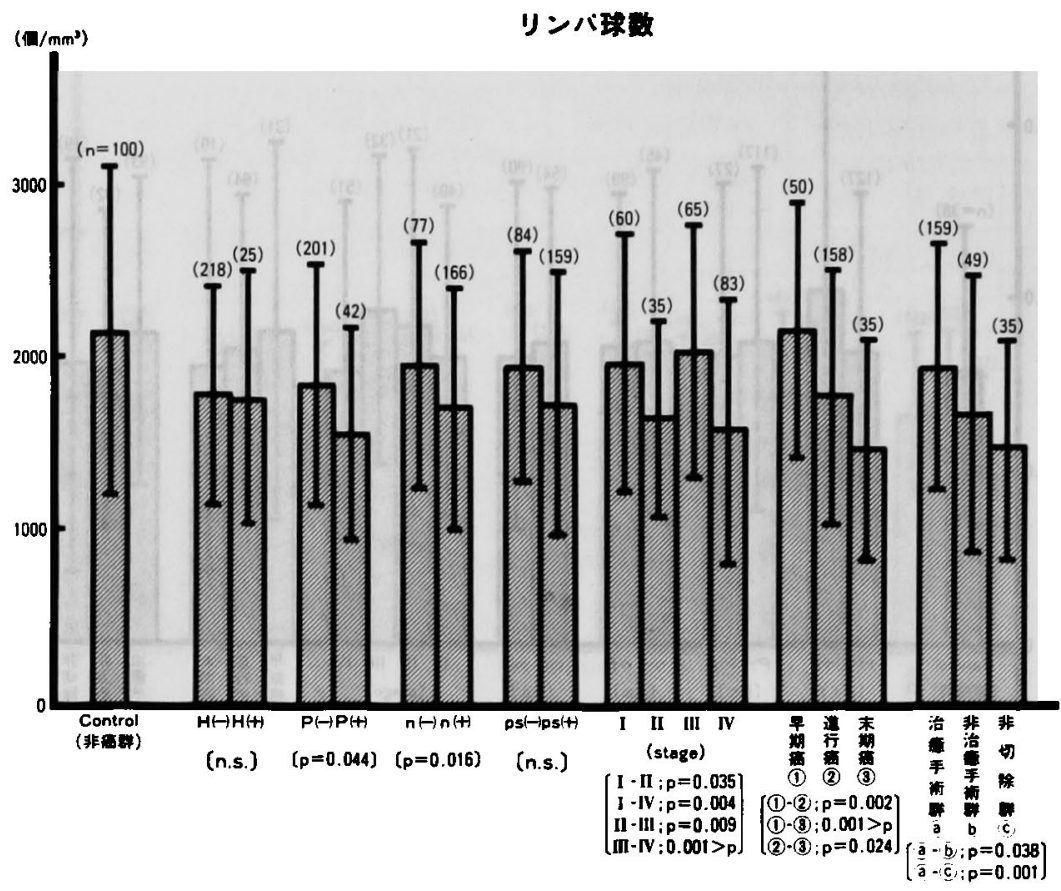

图 6 リンパ球数と我進行程度

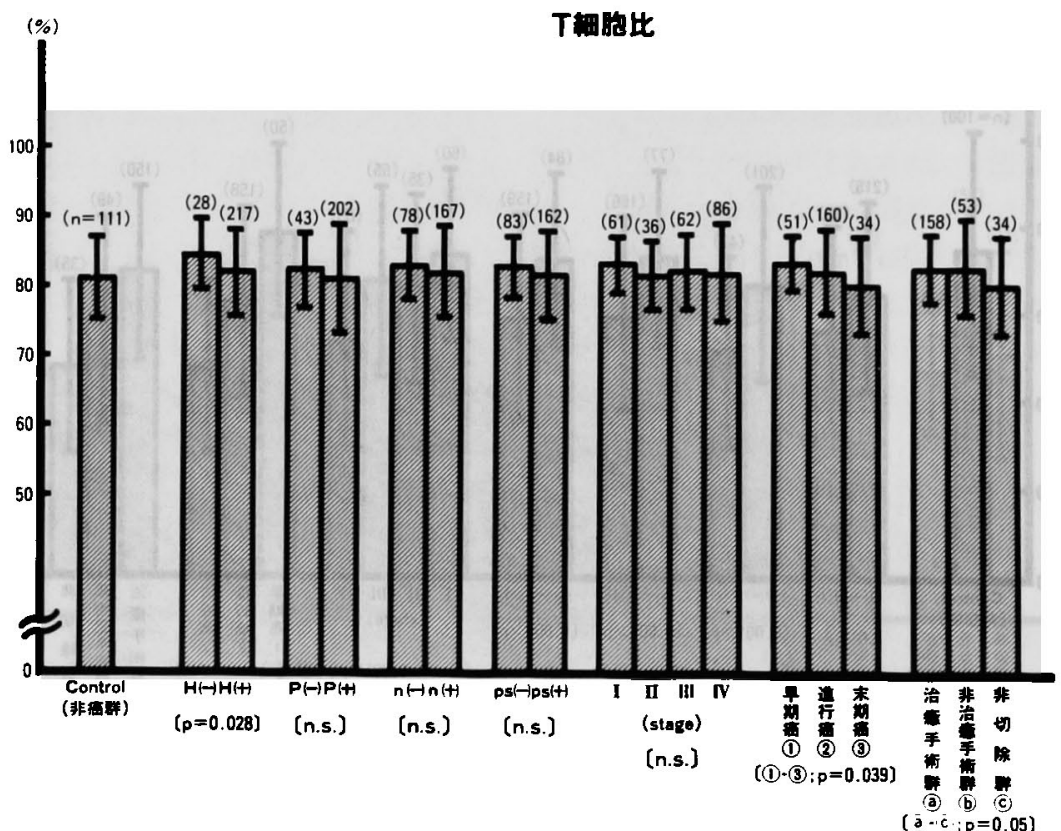

図 7 T 細胞比と䆵進行程度

すが、パラメータとしての有用性は少ない，有意差は stage I, stage II と stage IV との間でのみ認められ, stag IVで有意の高値がみられた。 又, stage IV に含
まれている非切除群ではむしろ低值を示す傾向がみら れ, ConA/PHA は, 癌の進行と共に濑増するがその ピークは切除可能な stage IVにあり, 末期に至っては 


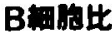

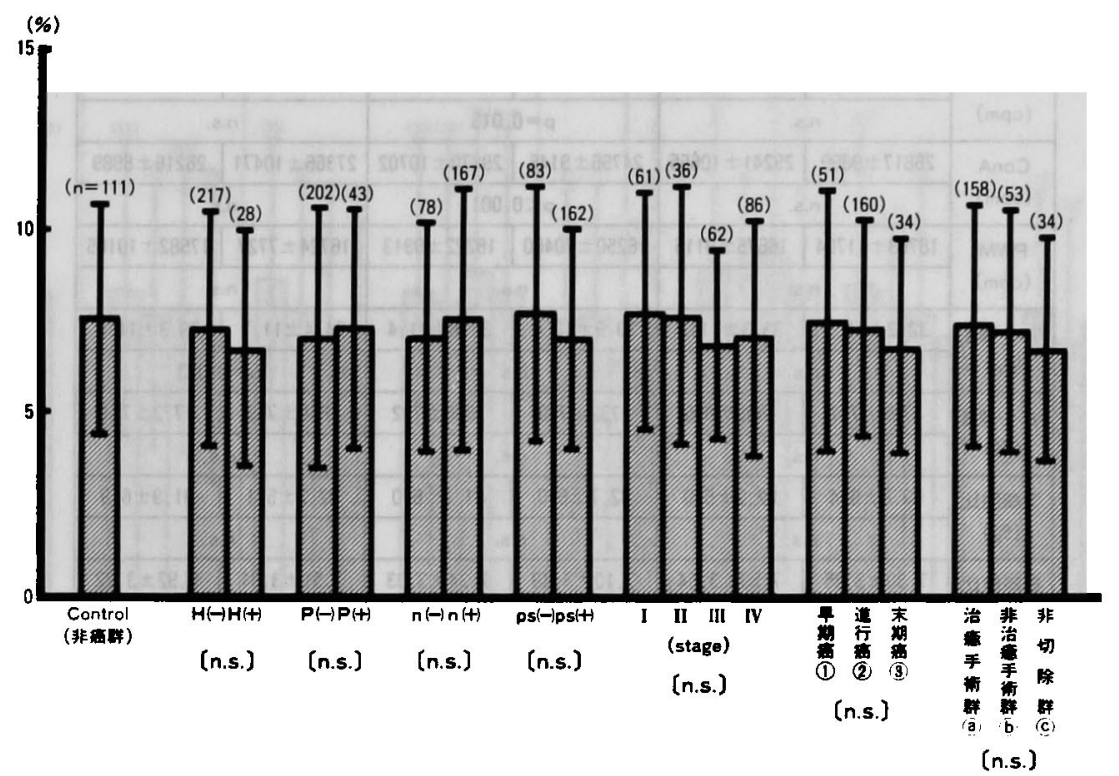

图 8 B 細胞比と禹進行程度

むしろ減少するすのと思われた.

(d) PWM (图 4)

PWM は癌の進行に伴う一定した傾向は示さず，有 意差すみられなかった。症例数は他のハララメータより 少ないか，有用なバラメータではなかった。

(e)リンパ球比（図 5)

リンバ球比は癌の進行に伴い一定した強い減少傾向 を示し，有用なバラメータと考えられた，有意差も $\mathrm{P}$ $(-)-(+), \mathbf{n}(-)-(+)$, ps $(-)-(+)$, stage I, II, III と stage IV, 早期一進行一末期の各群間及び治痗群 と非治腹, 非切除群との間で認められ，その意義は， 前述の PHA と同様であると考えられた。

(f) リンパ球数（图 6)

リンバ球数も全体として減少傾向を示したが, stage III で有意の高值が認められ、これが意義のあるすのか 否かは不明であり今後さらに検討を要すると思われ た. stage 別を除くとその変動はりンバ球比と似てお。 ク, バラメータとしての有用性はリンバ球比に及ばな いが一部巽なる変動るみられ，補助的な意味で有用性 があると思われた。

(g) T 細胞比 (困 7)

T 細胞比は著明なリンパ球の変動にかかわらず一 定値をとる㑯向がみられた，有意差は $\mathrm{H}(-)-(+)$ 間, 早期一末期群間, 治㿾一非切除群間でみられ, 末
期において，特に肝転移陽性例で有意の低値を示す様 であるがバラメータとしての意味は少ないと思われ た.

(b) B 細胞比（図 8)

$\mathrm{B}$ 紐胞比は弱い减少傾向があると思われたが一定し ておらず，有意差むないためバラメータとしての有用 性は認められなかった。

4. 年龄別, アルブミン値別および組織学的分化度別 の検討（表 5，図 9〜図12）

i）全症例における検討（表 5)

組織学的分化度別で有意差を示すバラメータはな かった，年龄別では，PHA，ConA が60歳以上群で有 意の低値を示し, 有意差の強さは $\operatorname{ConA}(\mathrm{p}<0.001)>$ PHA(p=0.015)であった. フルブミン值別で有意差を 示したのはリンバ球比のみで, リンバ球比は $4.0 \mathrm{~g} / \mathrm{dl}$ 未満群で有意の低值を示した．この結果は，前述の担 癌群における年龄, アルブミン值との相関と同じ結果 であった。

ii） stage 別にみた各バラメータの変動

ハララメータは癌進行程度に対し一定の傾向を示した PHA, ConA, ConA/PHA, リンバ球比を選び検討し た.

(a) PHA (図 9)

組織学的分化度別でみると，分化型，低分化型共に 
表 5 各パラメータと 2 群間検討(組織学的分化度別, 年齢別, 血清アルプミン值別)

\begin{tabular}{|c|c|c|c|c|c|c|}
\hline & 分 化 整 & 俟分化型 & 年令 60 才以上 & 年令60才未满 & 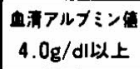 & 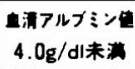 \\
\hline \multirow{2}{*}{$\begin{array}{l}\text { PHA } \\
\text { (cpm) }\end{array}$} & $38374 \pm 12560$ & $40880 \pm 11852$ & $36680 \pm 12028$ & $40563 \pm 13126$ & $38521 \pm 13009$ & $37917 \pm 12380$ \\
\hline & \multicolumn{2}{|c|}{ n.s. } & \multicolumn{2}{|c|}{$p=0.015$} & \multicolumn{2}{|c|}{ n.s. } \\
\hline \multirow{2}{*}{$\begin{array}{l}\text { ConA } \\
(\mathrm{cpm})\end{array}$} & $26817 \pm 9899$ & $29241 \pm 10655$ & $24756 \pm 9146$ & $29870 \pm 10702$ & $27366 \pm 10471$ & $26216 \pm 8989$ \\
\hline & \multicolumn{2}{|c|}{ n.s. } & \multicolumn{2}{|c|}{$\rho<0.001$} & \multicolumn{2}{|c|}{ n.s. } \\
\hline \multirow{2}{*}{$\begin{array}{l}\text { PWM } \\
\text { (cPm) }\end{array}$} & $18769 \pm 11704$ & $16675 \pm 9116$ & $16250 \pm 10460$ & $18222 \pm 9913$ & $16724 \pm 7727$ & $17582 \pm 10165$ \\
\hline & \multicolumn{2}{|c|}{ n.s. } & \multicolumn{2}{|c|}{ n.s. } & \multicolumn{2}{|c|}{ n.s. } \\
\hline \multirow{2}{*}{$\begin{array}{l}\text { 1ン八科比 } \\
(\%)\end{array}$} & $32.2 \pm 11.7$ & $33.3 \pm 11.7$ & $30.9 \pm 12.4$ & $32.8 \pm 11.4$ & $34.4 \pm 11.7$ & $29.3 \pm 11.2$ \\
\hline & \multicolumn{2}{|c|}{ n.s. } & \multicolumn{2}{|c|}{ n.s. } & \multicolumn{2}{|c|}{$p=0.003$} \\
\hline \multirow{2}{*}{ 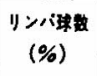 } & $1756 \pm 717$ & $1895 \pm 805$ & $1732 \pm 770$ & $1860 \pm 722$ & $1860 \pm 759$ & $1772 \pm 731$ \\
\hline & \multicolumn{2}{|c|}{ n.s. } & \multicolumn{2}{|c|}{ n.s. } & \multicolumn{2}{|c|}{ n. } \\
\hline \multirow{2}{*}{$\begin{array}{c}T \text { 梱胞比 } \\
(\%)\end{array}$} & $82.8 \pm 6.4$ & $82.2 \pm 5.0$ & $82.7 \pm 6.0$ & $81.7 \pm 6.0$ & $82.2 \pm 5.1$ & $81.9 \pm 6.9$ \\
\hline & \multicolumn{2}{|c|}{ n.s. } & \multicolumn{2}{|c|}{ n.s. } & \multicolumn{2}{|c|}{ n.s. } \\
\hline \multirow{2}{*}{$\begin{array}{c}\text { B細胞比 } \\
(\%)\end{array}$} & $7.30 \pm 3.35$ & $7.59 \pm 3.54$ & $7.10 \pm 3.39$ & $7.34 \pm 3.33$ & $7.51 \pm 3.31$ & $6.92 \pm 3.22$ \\
\hline & \multicolumn{2}{|c|}{ n.s. } & \multicolumn{2}{|c|}{ n.s. } & \multicolumn{2}{|c|}{ n.s. } \\
\hline
\end{tabular}

\section{PHA(stage別)}

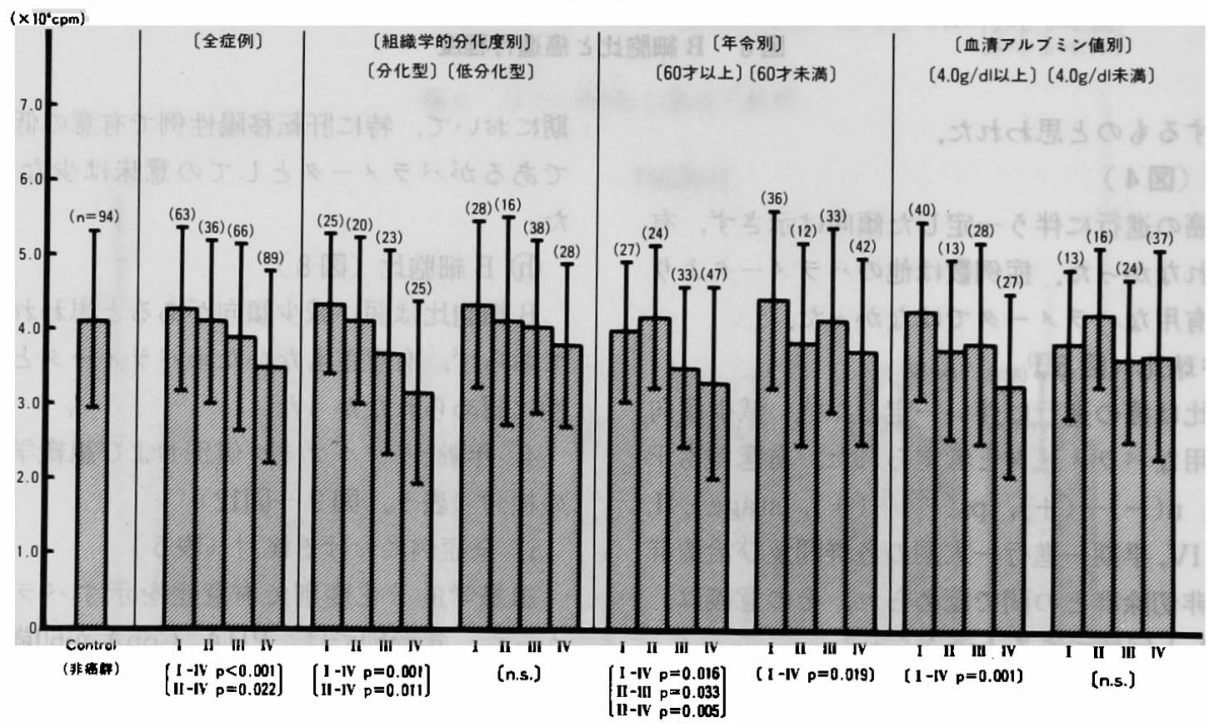

图 9 PHA：年齢別，血清アルフミン值別，組樴学的分化度別の検討

stageの進行に伴って減少する傾向がみられたが，そ の傾向は明らかに分化型において強く，PHA は分化 型でより良く stageを反映すると思われた。両群間の 同一 stage を比較してみると, stage I, II は両群間で 差はみられないが, stage III, IVに怙いて分化型で低 値を示す傾向がみられた. 有意差は, 分化型では stage I, II と stage IV との間でみられたか，低分化型では stage 間の有意差はみられなかった。 年齢別では, 両群
共に不完全な减少傾向を示したが，その変動のバター ンは異なっていた，60歳以上群では stage II と III の 間で段差がみられたが，60歳未満群では stage I と II の間で段差がみられ， stage II, III, IV ではとんど差は みられなかった. stage 間の比較では, stage I, III, IV は60歳以上群が低値を示したが, stage II は差が少な くむしろ60歳未満群の方が低檤を示す傾向がみられ た. 有意差は, 60歳以上群は stage I-IV, II-III, II 
ConA(stage则)

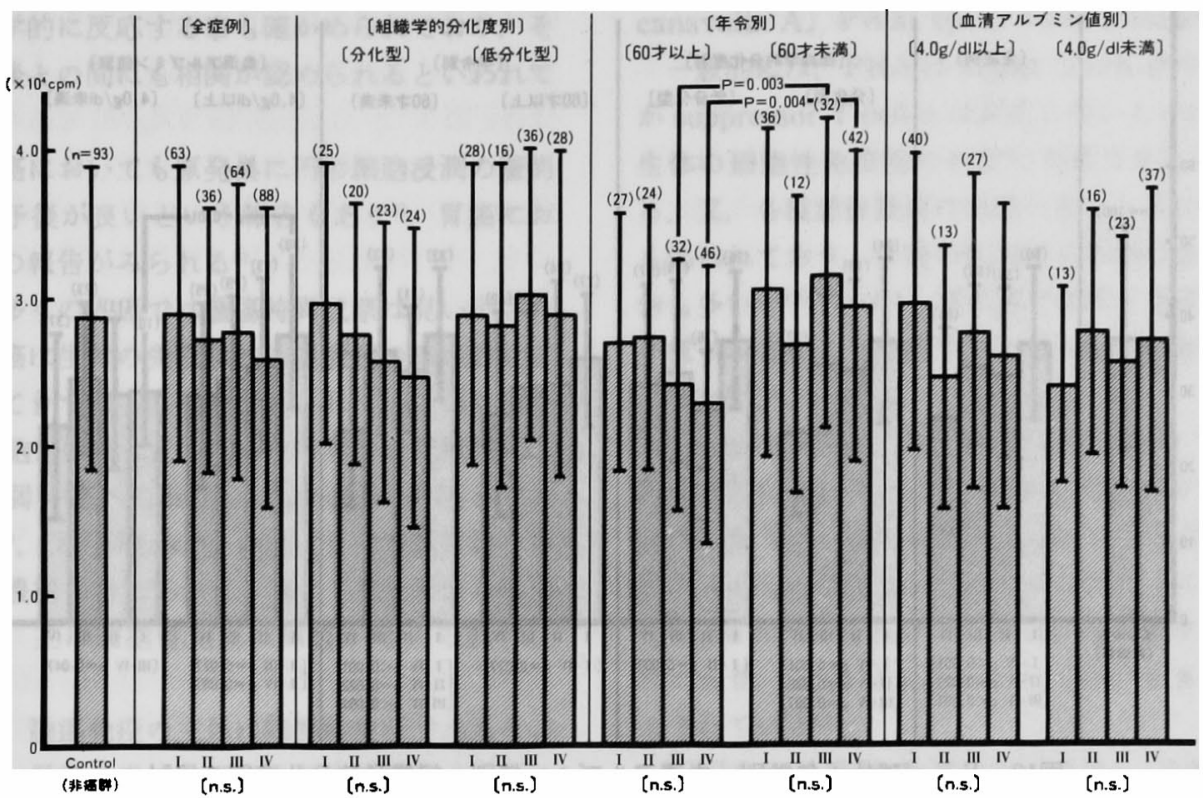

図10 ConA：年跲別，血清アルフミン值別，組織学的分化度別の検討

ConA/PHA(stage別)

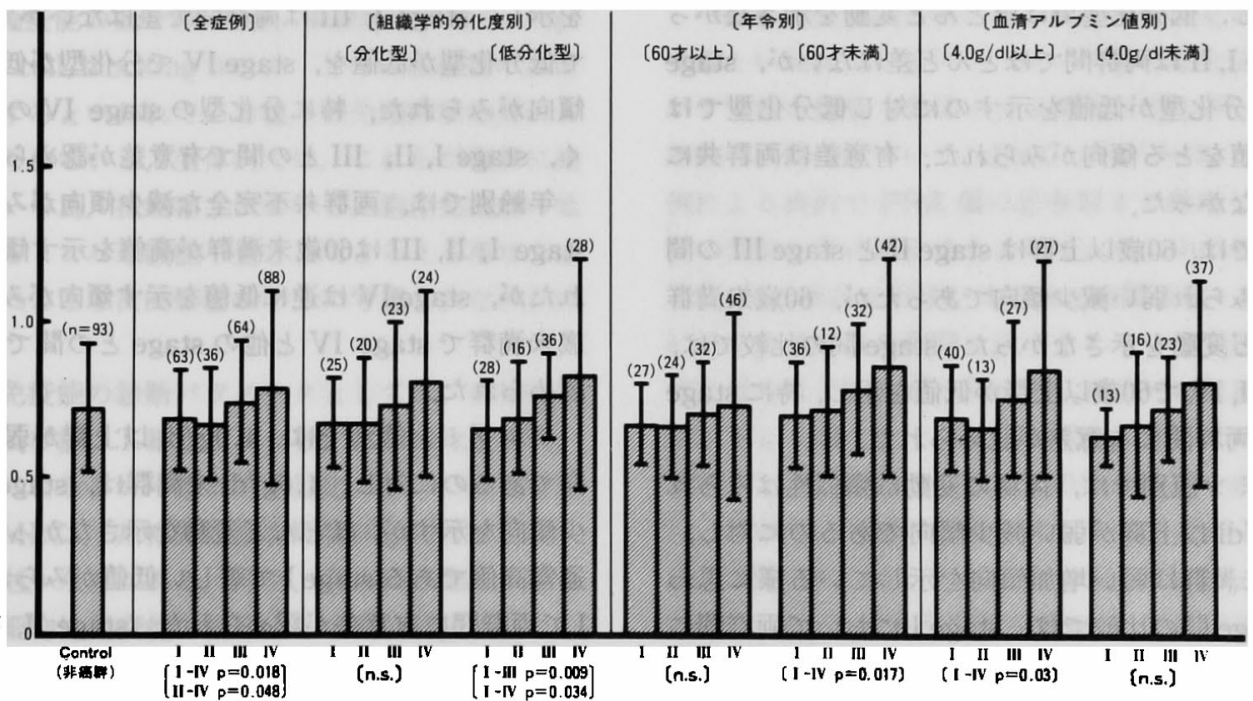

图11 ConA/PHA：年柃別，血清アルブミン值別，組織学的分化度別の検討

-IV 間で，60藏未満群は stage I-IV 間で認められ た.フルブミン値別では, $4.0 \mathrm{~g} / \mathrm{dl}$ 以上群は減少傾向を 示すのに対し， $4.0 \mathrm{~g} / \mathrm{dl}$ 末満群はほとんど変動を示さ ず减少傾向もみられなかった. アルブミン低値群は,
通常高値を示す stage I で高値を示さず，低值を示す はずの stage IV でも低值を示さなかった，有意差は， $4.0 \mathrm{~g} / \mathrm{dl}$ 以上群の stage I-IV 間でのみ認められた. (b) ConA (図10) 


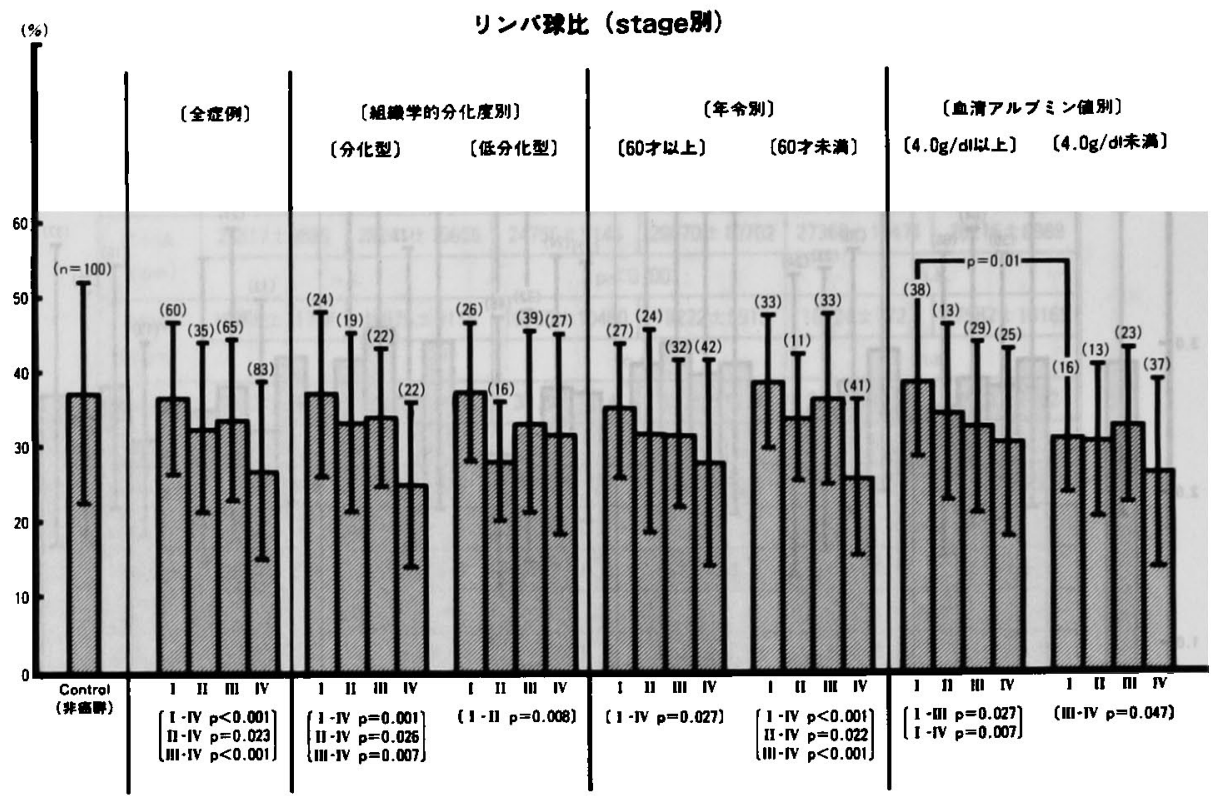

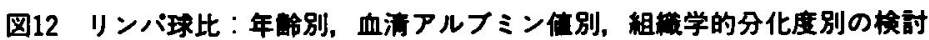

組織学的分化度別において両群の変動のバターンに 相違がみられた．分化型では stageの進行に伴い減少 傾向を示し全症例でみるより良く stageを反映してい るのに対し，低分化型ではほとんど変動を示さなかっ た. stage I, II は両群間でほとんど差はないが, stage III, IV で分化型が低值を示すのに対し低分化型では むしろ高值をとる㑯向がみられた，有意差は両群共に 認められなかった。

年龄別では, 60歳以上群は stage II と stage III の間 で段差がみられ弱い減少傾向であったが，60歳末満群 ははとんど変動を示さなかった. stage 間の比較では, stage I, III, IV で60歳以上群が低值を示し，特に stage III, IVで両群間に有意差が認められた。

アルブミン值別では，両群の変動に類似性はみられ ず, $4.0 \mathrm{~g} / \mathrm{dl}$ 以上群が弱い減少傾向であるのに対し， $4.0 \mathrm{~g} / \mathrm{dl}$ 末満群は弱い増加傾向を示している様に思わ れた. stage 間の比較では, stage I において両群間に 差がみられるが, stage II, III, IVでは両群間に大きな 差はみられなかった。

(c) ConA/PHA (図11)

ConA/PHA は背景因子による影製が少ないため, 各 2 群間の変動に大きな差はみられなかった。有意差 は，低分化型の stage I-III，I-IV，60歳未満群の stage I-IV, $4.0 \mathrm{~g} / \mathrm{dl}$ 以上群の stage I-IV 間でみら れ, 分化型, 60 歳以上群, $4.0 \mathrm{~g} / \mathrm{dl}$ 未満群では有意差は
認められなかった。

(d)リンハ球比（图12）

組織学的分化度別では，両群共に不完全な减少㑯向 を示し, stage I, III は両群間で差はないが, stage II で低分化型が低值を，stage IVで分化型が低值を示す 㑯向がみられた．特に分化型の stage IV の低值は強 く, stage I, II, III との間で有意差が認められた.

年龄別では，両群共不完全な减少傾向がみられた。 stage I, II, III は60歳末満群が高値を示す傾向がみら れたが, stage IVは逆に低值を示す傾向がみられ，60 歳末满群で stage IV と他の stage との間で有意差が 認められた。

フルブミン值別では, $4.0 \mathrm{~g} / \mathrm{dl}$ 以上群が弱い减少㑯 向であるのに対し，4.0g/ dl 未満群は, stage IV で成 少傾向を示すが，汪とんと変動を示さなかった。特に， 通常高値である stage I で著しい低值がみられ, stage Iで両群間に有意差が認められた. stage II, III, IVに おける両群間の差は少なかった. stage 別の有意差は, $4.0 \mathrm{~g} / \mathrm{dl}$ 以上群では stage I-III, I-IV 間で, $4.0 \mathrm{~g} / \mathrm{dl}$ 末満群では stage IIIーIV 間で認められた。

\section{IV. 考按}

1963年に Burnet ${ }^{2)}$ が免疫学的監視機構の概念を唱 えて以来，その反応を把挃する事により度の診断，治 療が可能となると考えられ種々の研究がなされ現在に 至っている，今日までの研究報告に上ると，一部の悪 
性腫焬には，腫場特異抗原が存在し，その抗原に対し 宿主は免度学的に反応する事も確かめられており，そ の反応と予後との間にも相関が認められるといわれて (いる3).

一方、人癌に怙いても原発巣に円形細胞漫潤の著明 なるのほど予後が良いといら報告すあり"，胃癌に拉 いてす同様の報告がみられる5).

しかし，多くの人澏では腫場特異抗原は見い出され ておらず。癌は生体の免度学的監視機構の綱の目を逃 れて発生してきている，その機序としては，発生初期 には NK 細胞が関与し，さらに免疫学的監視機桡によ り抗原性の弱い癌への immunoselectionが起るとい われている

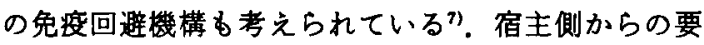
因としては，主に細胞性免度の障害が考えられてい， $3^{\text {s). }}$.

一般には，腫瘍免疫の主体は細胞性免疫であるとい われており，胃癌患者でる細胞性免疫が障害されてい るとする報告は多( ${ }^{91}$. 折田らは ${ }^{10)}$, 胃癌の進行程度と リンハ球幼若化率との間には明らかな相関があり、一 定値以下では手術的切除が不能であったと報告してい る.

細胞性免疫能の低下は，加龄，栄養障害の他に， suppressor T cell, blocking factor, さらに癌患者の血清 中に存在するといわれている種々の免度抑制物質によ ると考えられている.生体内では，これらが複雑に絡 久合っている為, 担癌宿主における細胞性免疫能の低 下は単なるリンパ球機能不全としてとらえる事はでき ず，担癌による2次的影響が十分に考虑されなければ ならない。

細胞性免度能の診断ハララメータとしては，末梢血リ ンバ球比及び数， T 細胞比及び数， B 細胞比及び数, mitogenによるリンバ球奻若化反応，リン八球混合培 養試験（MLC），非特異的細胞障害試耠（NK 活性， ADCC 活性)などがある，今回，著者は，臨床上測定 が容易で細胞性免疫能の指標として高く評価されてい るリンパ球幼若化反応を中心に，末梢血リンパ球比， リンハ球数， $\mathrm{T}$ 細胞比， $\mathrm{B}$ 細胞比を年龄と栄盖状態の 指標として血清アルブミン値を加え検討した。

リンパ球奻若化反応は種々の mitogenによりリン 八球が芽球化する反応である. 植物由来の mitogenは lectin と呼ばれ，糖蛋白よりなるいのでリンバ球分裂 促進活性を有し、リンハ球の抗原特異性とは無関係に 多数のリンパ球を幼若化させる ${ }^{11}$. 代表的なるのとし
ては, PHA (phytohemagglutinin), ConA (concanavalin A), PWM (poke weed mitogen) がある.

一般的には，PHA は helper T cell を幼若化させる が suppressor T cell とは反応しないといわれており， 生体の細胞性免疫能の判定に有用であるとされてい る. 又, 各種悪性蓮場の病期の進行と共に低下する事 る知られており，子後の判定にも有用であるとする報 告む多(12113). しかし, 癌の進行に伴 3 PHA の反応性 の低下がどのような因子によるものであるかは明らか ではない。

ConA は, helper $\mathrm{T}$ cell と suppressor $\mathrm{T}$ cell に反 応するといわれている14. ConA で誘導されたリンパ 球が正常リンパ球の各種 mitogenによる反応やMLC 反応 (mixed lymphocyte reaction) 及び PFC反応 (plaque forming cell responce) を㧕制する事が知ら れており，ConA は suppressor T cell を良く誘導する とされている15).

PWM は T 細胞, B 細胞共に刺激し, B 細胞を polyclonal な免疫グロブリン産生細胞へと分化させるが, これには helper T cell が必要であるとされている16). 一方，人においては $\mathrm{T}$ 細胞を優位に幼若化させるとい ら報告もみられる ${ }^{17}$.

一般に免疫能は加龄により細胞性免疫を中心に低下 するといわれている(1919). リン八球奻若化反応る老化 がすすむと障害されるとする報告が多い209. PHA と

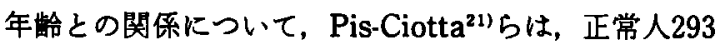
例による検討でPHA 值は思春期まで渐増し思春期以 後は加龄と共に隇少するとしている.中山らは221健康 人174例の検討で PHA は年龄と相関係数 $-0.336, \mathrm{p}<$ 0.05で有意の負の相関を示すとしている. ConA に関

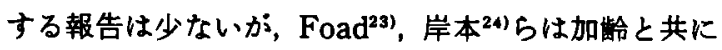
低下すると報告している，PWMに関しては低下する あの ${ }^{25)}$ と有意差なしとするすの ${ }^{18)}$ があり一定していな い. $\mathrm{T}$ 細胞は機能異常を示すとする文献がみられる26) が 細胞数に関しては一定の見解は得られていな い27128). 老化に伴5免疫能の変化は,リン八球自体の量 的, 質的変化, 老年者の血清中に存在するといわれて いる免废抑制因子 ${ }^{29)}$, helper-suppressor balance $の$ 乱 れなどによると思われるか，これが発癌とどのよらに かかわりあっているかは明らかでないが, 発癌の引き 金になる可能性は十分にあると考えられる。

今回の年秢と各バラメータとの検討によると, 非癌 群では, ConA $(r=-0.418)$, PHA $(r=-0.37)$, ) ン八球比 $(r=-0.314)$, リンパ球数 $(r=-0.216) か$ 
それぞれ年龄と負の相関を示し，相関の強さは ConA > PHA>リンバ球比>リンパ球数の順であっ た。一方，担癌群で相関を示したのはPHA（r=$0.171), \operatorname{ConA}(r=-0.333)$ のみで, リンパ球比, リ ンパ球数の相関は消失した。 PHA, ConA は両群で年 齢と負の相関を示し，従来いわれている如く年龄によ り強い影隌をうけ，その程度はC ConA > PHA であると 思われた。 PWM, T 細胞比， B 細胞比は年齢と有意の 相関を示さなかった，又，担癌群では非癌群より相関 を示すバラメータの数やそれぞれの相関係数が堿少す る傾向がみられ，年龄と各バラメータとの相関は担癌 により擋乱される事が示唆された．相関の強さの順序 は両群間で大きな差はみられず，担癌による擋乱の程 度は比較的均一であると思われた，対象を特定年龄で 2 群に分けて検討した報告は少ない。岸本ら ${ }^{30}$ は，60歳 以上と末満とに分け検討し，PHA，リンパ球数が60葴 以上群で有意の低值を示すとしている.新本ら ${ }^{311}$ は, 胃 癌患者を70歳以上と末満に分け，それぞれをさらに stage 別に椧討しているが，PHA，PWMに関しては 2 群間に有意差はなかったと報告している。著者の60 歳以上，未满群に分けての検討では，PHA， ConAの みが60歳以上群で有意の低値を示し，他のハララメータ は有意差を示さなかった。両群の stage 別の変動を比 較してみると，PHA，ConA 共に，60歳以上群の stage III, IV で低値を示す傾向がみられた。特に ConA では stage III, IV で両群間に有意差がみられ，その傾向は さらに強いようであった。リンハ球比は, stage I III は60歳未満群が高値を示すか， stage IVではむしろ低 值を示す傾向がみられ, 60歳未満群での stage IV の強 い低値が相関消失の一因であると思われた。

栄養障害が生体の免疫能に大きな影響を与えるとす る報告は多い，低栄養状態にある患者では，液性免疫 能, 細胞性免疫能共に低下するといわれている32).蛋白 カロリー栄美障害患者に扣いては， T細胞系の異常が 主体で B 細胞系の障害は強くなく， T 細胞減少， B 細 胞不変の結果 null 細胞が増加するとい、 ${ }^{33)}$. 又, リン 八球幼若化反応では，PHA，ConA 共に栄美障害によ クその反応性は低下するといわれている34)，栄養状態 の指標としては, 理想体重比, 通常体重比, 上腕筋囲, 血清総蛋白値，血清フルブミン値，クレアチニン身長 指数，血清トランスフェリン值，血清鉄，亜鉛值など がある。これらのらち最も良く全身の栄養状態を反映 するあのについて一定の見解はみられないか，著者は 血清アルブミン値をもって栄養状態の指標とし, 各ハ
ラメータとの夙連を検討した。佐藤ら ${ }^{35)}$ は, 胃癌患者と 様々な栄峑指標との関保を検討しており，フルフミン 値は良性 $4.1 \mathrm{~g} / \mathrm{dl}$, stage I $4.2 \mathrm{~g} / \mathrm{dl}$, stage II $3.7 \mathrm{~g} / \mathrm{dl}$, stage III $3.7 \mathrm{~g} / \mathrm{dl}$, stage IV $3.4 \mathrm{~g} / \mathrm{dl}$ であり，免疫バラ メータとの相関では，リンパ球比 $(\mathrm{r}=0.3)$ と PHA SI $(\mathrm{r}=0.31)$ かi $\mathrm{p}<0.05 て ゙$ 正の相関を示したと報告して いる. 今回の結果では, 良性 $4.16 \mathrm{~g} / \mathrm{dl}$, stage $\mathrm{I} 4.2 \mathrm{~g} /$ $\mathrm{dl}$, stage II $3.86 \mathrm{~g} / \mathrm{dl}$, stage III $4.12 \mathrm{~g} / \mathrm{dl}$, stage IV $3.86 \mathrm{~g} / \mathrm{dl}$ であり，佐藤らの報告と比へ， stage III, IV でも比較的良くアルブミン値が保たれている特徵がみ られた，相関の検討では，非癌群において ConA（r= $0.339)$, リンパ球比 $(r=0.193), T$ 細胞比 $(r=0.251)$ が正の相関を示し，相関の強さは ConA $>\mathrm{T}$ 細胞比> リンハ球比の順であった。 PHA，リンバ球数，B細胞 比はアルブミン值との相関は示さなかった。一方，担

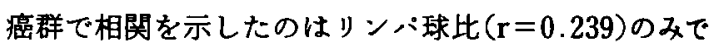
あり，非癌群で強い相関を示した ConA， T 細胞比の相 関は担癌群ではみられなかった。しかもリンハ球比 の相関係数は担癌群でむしろ増加する様であった。年 龄，フルプミン值と免疫ハララメータとの相関を，非癌 群, 担癌群で比較した文献はほとんどみられないか， 著者の見解としては，各パラメータは程度の違いはあ るが年龄や栄養状態により影響をうけていた。 その相 関は，担癌あるいは担癌による 2 次的因子により擋乱 される. 又, 擋乱の程度は，年㱓々の相関では比較的 均一であるのに対し，アルブミン值との相関ではバ メータにより異なると思われた。フルブミン值により 対象を 2 群に分けて検討した文献はほとんどみられな い.今回のアルプミン值 $4.0 \mathrm{~g} / \mathrm{dl}$ 以上と末满とに分け ての検討で，両群間で有意差を示したのはリンハ球比 のみで,リンパ球幼若化反応は有意差を示さなかった。 両群の stage 別変動をみてみると，4.0g/dl 未満群で PHA, ConA, リンハ球比の stage 間の変動が消失する 傾向がみられた，特に通常高値を示す stage I での低 值傾向が強く，ConA では stage Iが他の stage より低 値を示し、ソンバ球比では, stage Iにおいて両群間に 有意差が認められた。しかし， stage II, III, IV におけ る低アルプミン状態による影響は明らかでなかった。

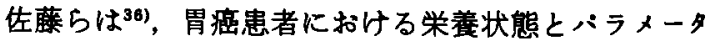
との検討で，栄羡状態を一定にするとほとんどの非特 異的兔疫指標の stage による差はみられなくなったと 報告しているが，著者の見解としては，低栄着群にお いてのみそのような傾向がみられ，低栄養状態により 生体の免疫能は量的, 質的にかなり強い障害をうける 
が，その障害の程度は担癌状態により異なると思われ た。しかし，栄養障害に上る免度能の低下は臨床栄養 状態の改善により丑速に回復するとされておらり ${ }^{38)}$ ，担 癌宿主の栄盖状態の改善が兔疫能にとって極めて重要 である事が示唆されるるのと考えている。

非特異的免疫ハシラメータ相互の相関やそれを非癌 群, 担癌群で比较した文献はほとんどみられない、今 回の結果では，担癌群でより多くのバラメータ相互の 相関がみられ，非癌群で相関を示したタルーブは B 細 胞比一リンバ球数を除きすべて担癌群です相関が認め られた。これは前述の如く，症例数の多い担癌群の方 が非癌群より相関が認められやすいといら統計学的性 質之矛盾せず,担癌群で多少その相関は乱れるむのの, 両群間に大きな差はなく，担癌生体内におけるバラ メータ間のハラランスはさほど乱されないと思われた。 例外は, 非癌群での相関が担癌群で消失した B 細胞比 ーリンパ球数と非癌群で $\mathrm{r}=-0.748$ と極めて強い相 関が担癌群では $\mathrm{r}=-0.268$ と著しく相関の減弱がみ られた B 細胞比一T 細胞比である。これらは共に B 細胞比が関与しており，担癌により $\mathrm{B}$ 細胞系と他のハ ラメータとのバランスが強く乱される事が示唆され た.全体としては両群間に大差はないと考え,パラメー タ相互の相関を担癌群でリンバ球幼若化反応に関して 検討すると，PHA, ConA, PWM は互いに強い正の相 関を示し，その強さは，PHA-ConA $>$ Con $A$ 一PWM>PHA-PWMの順であった. 又, PHA, ConA, PWM はすべて T 細胞比と正の相関を示した が, 相関の強さは PWM > PHA >ConA の順であり，

最も T細胞系と相関しないと考えられた PWMが T 細胞比と最も強い相関を示した。

担癌状態を反映するパラメータが見い出されたなら ば, 癌の進行程度, 治療効果や予後の推定, さらに効 果的な治㞠のための指標とする事ができる．そのため 多くのバラメータと癌進行程度との関係が娭討されて いる, 矢田 $\left.{ }^{38}\right)$ は, ハラ 患者の病期, 病巣の進展との相関. (2) 予後の良否や無 症期間の長短との相関. (3) 治療効果と平行して变動す る. (4) 2 次的免疫抑制状熊の把握. (5) 免疫賦活剂因 子の投与時期の推定.をあげており，ハラメータとし て, 末梢リンパ球数, PHA 皮内反応, PHA リンハ球 幼若化反応が有用であるが，いずれが最む良いかは未 た結論を出していない，今回の著者の検討は，矢田の あげた(1)と(4)及びバラメータの意義に主眼をおいたる のである，测定しえたバラメータは，PHA， ConA，
PWM 及びそれぞれの S.I. (stimulation index), 末梢 血リンハ球比， $\mathrm{T}$ 細胞比， B 細胞比及びそれぞれの絶 対数と反応性比率 ConA/PHA の13頃目である.PHA SI がパラメータとして有用であるとの報告すみられ

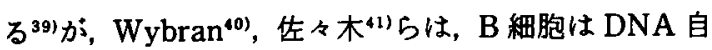
然合成能を有して扣り PHA 非添加群の ${ }^{3} \mathrm{H} \cdot \mathrm{TdR}$ と り込みのカウント数は B 細胞の量的差を反映してい るためS.I.の測定は不適当であると述べている．著者 のデータでもS.I.值はばらつきが多く有用なバラメー タとは思われなかった， $\mathrm{T}$ 細胞数， B 細胞数の変動は リンパ球数之類似し，リンパ球数の变化にまさるもの と思われなかった為今回の検討から除外した。結果と して, 癌進行程度に対し一定の㑯向を示したバラメー タは, PHA, ConA, リンパ球比, リンパ球数, ConA/ PHAであった。これらのらち癌進行程度のバラメー タとして有用と思われたのはPHAとリンバ球比で あったが単独では十分とはいえず, PHA，リンハ球比 を中心に, ConA, ConA/PHA, リンバ球数を加之総合 的に判断すべきであると考える. PHAについては,

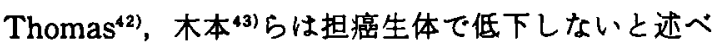
ているが，ハシラメータとして有用であるとする報告は 多(44)45). 折田らは(13)は，胃癌患者を stage I IV，さ らに stage IV を切除群と非切除群とに分け検討し, PHA と癌進行度との間には逆相関があり,一定值以 下では切除不能の可能性が高いと報告している。今回 の検討では, PHAは癌の進行に伴い明らかな减少傾 向を示し, ps(一)一(+)間, stage I-IV, II-IV 間, 早期一進行一末期の各群間, 治瘦群と非治瘁, 非切除 群間で有意差が羿められ，此較的早期のものとかなり 進行したるのとの判別に有用である. 特に早期癌, 進 行癌, 末期癌の判別や治瘦切除可能か否かの有用な指 標となりらるるのと考党るが，折田らが述べているほ どの有用性は示さなかった. ConA, PWM と癌進行程 度との関係を検討した報告は少ない、今回の結果では， ConA は全体として弱い減少傾向を示し, 有意差は早 期群, 進行群と末期群との間及び治寉群と非切除群間 で認められ，非切除となるよらな症例で有意の低値を 示すが、ハラメータとしての有用性は少ない.PWM は 癌進行程度に対し一定の㑯向は示さなかった。末梢り ンパ球比と癌進行程度との報告る少なく、多くはリン 弪球数で検討されている、リンバ球数がバラメータと して有用であるとする報告は多く46447，凮井らは48)、リ ンパ球数の著しい減少は広範なリンバ節転移を筑うと している. 今回の結果では, リン八球比, リンバ球数 
共に, stage II, III を除くと同様の変動を示した，有意 差 \& $\mathrm{P}(-)-(+), \mathrm{n}(-)-(+)$, 早期一進行一末期, 治复群と非治空，非切除群の各群間で同様に認められ たが, ps(一)ー(十)間はリンハ球比のみで認められた。 stage 別の変動は異なり，リンパ球比は潮减傾向で stage IV と他の stage との間で有意差がみられたの に対し、リンパ球数は, stage II の低值, stage III の 高値がみられ，有意差も stage I-II, II-III, III-IV, I一IV間で認められた。バラメータとしての有用性は リンパ球比の方が勝っていると思われた，リンハ球数 の stage II の有意の低値, stage III の有意の高値は他 の報告ではみられず,その意味については不明である。 しかし, 最近, 癌の経過中に免疫動態が変化する可能 性を示唆する報告がみられ，脾缄は担癌時期により免 度能を促進する時期と逆に抑制する時期があるとの報 告むあり 4950)，生体の免疫能は担癌の経過中にその応 答形式を変える可能があると考えられるよ5になって きている．著者す同様の見解を持っているがその現象 をとらえる事は極めて難しく，今後の課題にしたいと 考えている. $\mathrm{T}$ 細胞比， $\mathrm{B}$ 細胞比と癌進行程度との関 係は一定した見解は得られていない，今回の結果です 有意の変動はみられず，バラメータとしての有用性は 乏しいと考えられた。反応性比率 ConA/PHA は，同

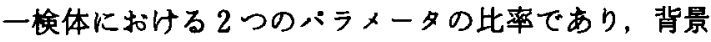
因子からの影響を除外して評価できる利点がある，中 神ら ${ }^{51}$ は, 癌の進行と共に ConA/PHA は漸増し、つい には逆転，すなわち ConA/PHA $\geqq 1.0$ となる症例がる えてくるとしている。折田ら ${ }^{131}$ は, ConA/PHA 11.09

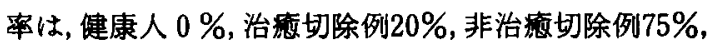

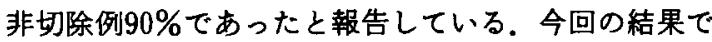
は，ConA/PHA は一定した弱い増加傾向を示したが， 有意差はstage I, II と stage IV との間でみられたの みであった. 又, stage IV は非切除群を含んでいるが， stage IV は非切除群より高値を示寸傾向がみられ, ConA/PHAのピークは切除可能な stage IV 群であ ろ5と思われた。これは前述の如く，非切除群では ConA b強い低値を示す傾向があり ConA/PHA b低 值となるのではないかと考えた，表 6 は，今回の検討 症例における ConA/PHA 1.0 占める割合を表に したものである. stage I $1.58 \%$, stage II $8.33 \%$, Stage III $4.68 \%$, stage IV $19.31 \%$ (切除可能群 $23.52 \%$ ，切除不能群 $13.51 \%$ ）であった。 やはり，切 除可能な stage IVにビークがあり， stage I, III との 間に $X^{2}$ 検定で有意差が認められた，又，ConA/
表 6 Con A/PHA ミ1.0の占める到合

\begin{tabular}{|c|c|c|c|c|}
\hline \multicolumn{2}{|c|}{ クループ } & $\begin{array}{l}1.0 \text { 以上 } \\
\text { 应例数 }\end{array}$ & $\%$ & \multirow{9}{*}{ 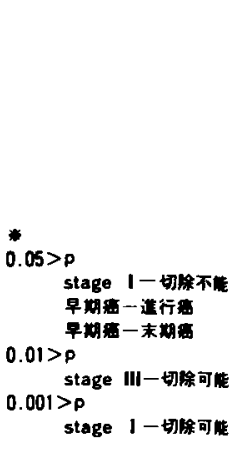 } \\
\hline \multicolumn{2}{|c|}{ stage 1} & $1 / 63$ & 1.58 & \\
\hline \multicolumn{2}{|c|}{ stage II } & $3 / 36$ & 8.33 & \\
\hline \multicolumn{2}{|c|}{ stage III } & $3 / 64$ & 4.68 & \\
\hline \multirow{2}{*}{ stage IV } & 切除可能 & $12 / 51$ & 23.52 & \\
\hline & 切除不期 & $5 / 37$ & 13.51 & \\
\hline \multicolumn{2}{|c|}{ 早胡虫群 } & $1 / 51$ & 1.96 & \\
\hline \multicolumn{2}{|c|}{ 進行落群 } & $18 / 163$ & 11.04 & \\
\hline \multicolumn{2}{|c|}{ 末期我群 } & $5 / 37$ & 13.51 & \\
\hline
\end{tabular}

PHA $\geqq 1.0$ 示したのは260例中24例 (9.2\%)のみで, 折田らの結果とは異なるが24例中17例 (71\%) が stage IV であり術前值で ConA/PHA か1.0以上の症例の予 後は良くないといえるであろう（表 6 ）.

非特異的免疫能と胃癌の組織型との関保を検討した 文献はほとんどみられない。胃癌の組型は， Lauren $^{52)}$ 加提唱して以来, 発生学的に分化型（腸上皮 型）と末分化型（びまん型）に分けて考えられる傾向 にある. 中村 ${ }^{53)} 55 \mathrm{~mm}$ 以下の铛小癌の検討でも同様の 結論を得ており，分化型（腺管形成癌，腸型の癌）は， 腸上皮化生を発生母地とし，一般的には細胞自由面に 小皮縁を有し粘液産生細胞は少ない，一方，末分化型 （腺管を形成しない癌，胃型の癌)は胃の固有粘膜を発 生母地とし，稩胞質に粘液産生が認められ小皮縟を有 さないとしている。これらは，疫学的にも明らかな差 がみられ，前者は，高龄者，男性に多く，肝転移の䫅 度は高いが腹膜播種はほとんどみられない，後者は， 若年者，女性に多く，肝転移は少ないか腹膜播種が多 い特改がみられる。このよ5に2つの異なるタイプ 癌において，その発生初期の免疫応答や発生後の免疫 能に与える影䇾は異なっている可能性がある，特に， 後者は免疫能が比較的良く保たれている若年者に多い 事などを考えるとこれらを分けて娭討する必要がある と思われる．両者は中間型す存在し必ずしす2つに分 類する事は容易でないが predominant な組樴型で分 類せざるをえない，具体的な組織型としては，前者は， 乳頭状腺癌 (papillary adenoca.), 管状腺癌 (well, moderately diff. tubular adenoca.)，後者は，粘液細 胞性腺癌 (signet ring cell ca.), 硬性腺癌 (poorly diff. adenoca.）と考えて良い. mucinous adenoca.をどち らに入れるかは難しいが，今回は媵者に入れ検討した。 
今回の結果では，分化型，低分化型の 2 群間で有意差 を示したハランータはなかった，両群における stage 別の变動をみてみると, PHA は分化型，低分化型共に stageの進行に伴い減少傾向がみられたが，明らかに 分化型でその傾向は強く，PHAのバラメータとして の有用性は分化型で高く，低分化型では低くなると思 われた. 又, 両群の同 stage間を比較してみると stage I, II での差は少なく， stage III, IVにおいて分化型で 低值を示す傾向がみられた。PHAでみる限り分化型 の stage III, IV で免疫能の低下が強く，免疫賦活浏の 良い適応となると思われた. ConA における両群の変 動の差はさらに強く，分化型では stage の進行と共に 减少㑯向を示すのに対し，低分化型ではほとんと变動 を示さなかった. ConA は helper T cell, suppressor T cell といら相反する因子を共に誘導するため，ての 変動は相殺されてしまら可能性があり，有意差はない が全症例でみるより明らかに分化型でハラメータとし ての有用性は高まると思われた，又，低分化型で変動 がみられなかったのる，T細胞の subsets レベルで変 化している可能性もあり, ConA の測定意義はけして 少なくないと考えられた。ConA/PHAは両群共に stage の進行と共に增加する傾向がみられ，両群間に 大きな差はみられなかった。低分化型で多少 stage を 良く反映する様であり，有意差も分化型ではみられな かったが低分化型では stage I と stage III, IV との間 で認められた. ConA/PHA は平均値でみると背景因 子にかかからず一定した増加傾向を示すが，その程度 は弱くパラメータとしては補助的な意味合いが強い。

しかし，個々の症例における PHA と ConA の反応性 の相違，及びその経時的変化をとらえるのに適してお $\eta$, 前述の ConA/PHA $\geqq 1.0$ 症例の検討も含め, その 意義は大きいと思われた。

\section{V. 結 語}

今回，著者は，リンパ球幼若化反応を中心に非特異 的免疫パラメータの有用性と意義, 年齢, 栄養状態と の関係, 組織学的分化度別の変動を検討し, 次の如き 結果を得た。

1. 年龄と各パラィータとの相関は, ConA $>\mathrm{PHA}>$ リンハ球比>リンハ球数の順で有意の負の相関がみら れたか， PWM， T 細胞比， B 細胞比は相関を示さな かった，又，その相関は担癌により擋乱されるが，各 バラメータに拈ける傥乱の程度に大きな差はみられな かった．年龄60歳以上群，未満群の両群間で有意差を 示したのはPHA とConAのみであり，共に60歳以上
群で有意の低値を示した。両群の stage 別変動では, 60 歳以上群の stage III, IV における PHA, ConA の低値 がみられ，特に, ConA では両群間で有意差が認められ た.

2. フルブミン值と各バラメータとの相関は，非癌群 ではConA > T 細胞比>リン八球比の順で正の相関が みられたが，担癌群で相関を示したのはリンパ球比の みであった。その相関は担癌により強い擋乱をらけ， 擋乱の強さはハララメータにより異なると思われた。フ ルブミン值 $4.0 \mathrm{~g} / \mathrm{dl}$ 以上, 未満の両群間で有意差を示 したのはリンハ球比のみで, $4.0 \mathrm{~g} / \mathrm{dl}$ 末満群で有意の 低值がみられた. 両群の stage 別変動では, $4.0 \mathrm{~g} / \mathrm{dl}$ 末 満群で PHA, ConA，リンハ球比の stage に上る変動 が消失する傾向がみられ，特に通常高值を示す stage I の低值傾向が強く、リンパ球比では stage Iにおいて 両群間で有意差が認められた。

3. ハランータ相互の相関は, リンパ球幼若化反応間 では, PHA-ConA $>$ ConA-PWM $>$ PHA-PWM の順で正の相関がみられた。 PHA, ConA, PWM は共 に T 細胞比と正の相関を示し，その強さはPWM> PHA>ConA の順であった。非癌群と担癌群との間で 大きな差はみられなかったか， $\mathrm{T}$ 細胞比一B 細胞比,

$\mathrm{B}$ 細胞比一リンハ:球数間の相関が両群間で特異な差を 示し, 担癌により $\mathrm{B}$ 細胞系と他のパラメータとのハラ ンスに乱れが生じる可能性が示唆された。

4. 癌進行程度を示すパラメータとしての有用性が あると思われたのはPHAとリン球比であり，共に 癌の進行に伴い明らかな減少傾向を示し, 早期癌, 進 行癌, 末期癌の判別や治痖切除か可能か否かの判断に 対し，有用な指標となりらる。ＣｏnA，リンバ球数， ConA/PHA は癌進行程度に伴い一定の傾向を示す が，ハラメータとしての有用性は少なく，PHA、リン 八球比を中心にこれらのハラォータの特性を加え, 年 㱓，栄盖状態などを考虑に入れて総合的に判断すべき である. ConA/PHA は, 癌の進行と共に増加する傾向 を示すが，そのピークは切除可能な stage IVにあり， 切除不能例ではむしろ减少する㑯向がみられた。 ConA/PHA $\geqq 1.0$ 以上を示したのは，24/260と 1 割弱 であったが，そのらち17例（約71\%）が stage IVであ り, 術前 ConA/PHA が1.0以上の症例の予後は良くな いと思われた。

5. 組織学的分化度別の検討で, 分化型之低分化型と の間で有意差を示すバラメータはなかった. stage 別 の変動では, PHA は両群共に減少傾向を示したが,そ 
の傾向は明らかに分化型で強く，分化型でより良いハ ラメータとなると思われた。ConA は, 分化型では隇少 傾向を示すのに対し，低分化型でははとんど変動を示 さなかった. PHA, ConA 共に, stage III, IV で両群 間の差は大きく，分化型の stage III, IV に拈ける免疫 能の低下が示唆された。

以上, 術前未治療時の胃癌患者 260 例之非癌患者 112 例の非特異的免疫能をりン八球幼若化反応を中心に検 討し，各パラメータが，年踰や栄盖状態に少なからぬ 影響をらけ，その影響が担癌や担癌状態により異なる 事, 各バラォータの有用性および胃癌患者の免疫能を 検討する際，分化型，低分化型に分けて考える必要が ある事などを，ある程度示唆する事が出来たと考えた。

稿を終るにあたり御指導, 御校闃を戴いた恩師庄司佑教 授に深く感謝の意を表します，又，御指導，御協力を戴きま した当外科教室金内秀士助教授及び本学泌尿器科中神義三 助教授に深く感謝致します。この研究に御協力を賜りまし た教室諸先生方及び本学数学教室伊藤高司講師に心より感 謝致します。

尚, 本論文の要旨は，第18回日本消化器外科学会総会, 第 19回日本癌治療学会総会, 第52回日本医科大学医学会例会 において発表した。

\section{文献}

1）胃癌研究会：外科・病理．胃澏取扱い規約（改訂第 10版)，金原出版，1979.

2) Burnet, F.M.: The evolution of bodily defence. Med. J. Aust., 2: 817, 1963.

3) Eilber, F.R. and Morton, D.L.: Impaired immunologic reactivity and recurrence following cancer surgery. Cancer, $25: 362,1970$.

4）浜崎美景, 沢山 興, 栗矢 勉: 胃のリンバ球様漫

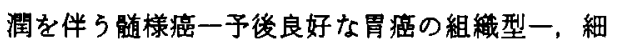
胞核病理誌，12:115，1968.

5) Black, M.M., Freeman, C. and Mork, T.: Prognostic significance of microscopic structure of gastric carcinomas and their regional lymphonodes. Cancer, $27: 703,1971$.

6）長井忠則：担癌生体の細胞性免疫に関する研究. 第 2 報。胃癌患者りンハ球の PHA 反応と血清中 の反応抑制因子の本態，札䖧医誌，46(6)：474, 1977.

7) Currie, G.A.: Cancer and the immune response. E. Arnold, London, 1974.

8）菊地浩吉：がん免疫の成立と排除機楧, 綜合臨床, $22: 2146,1973$.

9）金谷 隆：癌患者における稩胞性免度能に関する
研究. 第 1 報。澏患者末梢りン八球のPHAによる 幼若化現象について，札蜆医誌，43：48，1974.

10）折田苙三，林茂夫，晹村正二：末梢リン八球の免 疫学的活性に上万癌進行度々予後の判定, 手術, $29: 949,1975$.

11) Nowell, P.C.: Phytohemagglutinin: An initiator of mitosis in cultures of normal human leu cocytes. Cancer, $20: 462,1960$.

12) Eilber, F.R.: Sequential evaluation of general immune competence in cancer patients; correlation with clinical course. Cancer, $35: 660$, 1975.

13）折田葶三：癌患者の免疫機能, 臨床免度, 14(7)： $580,1982$.

14) Moretta, L. and Webb, S.R.: Functional analysis of two human T-cell subpopulation: Help and suppressor of B-cell responses by $T$-cells bearing receptors for IgM or IgG. J. Exp. Med., $146: 184,1977$.

15) Rich, R.R. and Rich, S.S.: Biological expressions of lymphocyte activasion. IV. Concanavalin A-activated suppressor cells in mouse mixed lymphocyte reactions. J. Immunol., 114 : $112,1975$.

16）矢田純一：ヒト B 細胞の免疫ダロブリン細胞へ の分化に対する T細胞の影幚について，臨床免 疫, 8:1129, 1976.

17) Sakane, T.: Studies on cell-mediated immune responses by human lymphocytes in vitro, 臨床 免度， $7: 1193 ， 1975$.

18）今井浩三：高龄者の細胞性免疫能に関する研究， 臨床免度，8(4)：433，1976。

19）岸本 進：兔度からみた老化. 日内会誌，68(3)： 263, 1979.

20) Hallgren, H.M.: Lymphocyte phytohemagglutinin responsiveness, immunoglobulins and auto-antibodies in aging humans. J. Immunol., $111: 1101,1973$.

21) Pis-Ciotta, A.V. and Westring, D.W. : Mitogenic effect of phytohemagglutinin at different ages. Nature, $215: 193,1967$.

22）中山志郎，星野 孝：加跉現象と主に末梢血りン 八球幼若化現象からみた免度機構の変退, 臨床免 疫, 4(10):1011, 1972.

23) Foad, B.S.I.: Phytomitogen responses of peripheral blood lymphocytes in young and older. Clin. Exp. Immunol., $17: 657,1974$.

24）岸本 進, 富野新八郎：老化に伴うヒ卜 T 細胞機 能の变化，取新医学，33(5)：879, 1978. 
25) Teasdale, C.: Age dependence of $T$ lymphocytes. Lancet, $1: 1410,1976$.

26) Callard, R.E. : Immune function in aged mice. 1. T-cell responsiveness using phytohemagglutinin as a functional probe. Cell Immunol., 31 : 13, 1977.

27) Reddy, M.M. and Goh, K.: $B$ and $T$ lymphocytes in man. IV. Circulating $B, T$ and null lymphocytes in aging population. J. Geront., $34: 5,1979$.

28) Weksler, M.E. and Hütteroth, T.H.: Inpaired lymphocyte function in aged humans. J. Clin. Invest., $53:$ : 99, 1974.

29）津田忠昭，辻本真人：老年者血清の PHA および PWM 刺激リンハ球培旡におよぼす抑制作用，日 本老年医学会䧴誌, 17(5)：511，1980.

30) Kishimoto, S.: Immune responses in aged mice. Changes of antibody-forming cell precursors and antigen-reactive cells with aging. Clin. Exp. Immunol., 8 : 957, 1971.

31）新本 稔，服部孝雄：老年者胃癌の治燎一免度癔 法一, Geriatric Medicine, 21(6)：1009, 1983.

32) Good, R.A. and Jose, D.: Immunodeficiency secondary to nutritional deprivation. In "Immunodeficiency in man and animals". Sinauer Associat. Sunderland : 219, 1975.

33）松本脩三: 栄美障害と免度不全, 臨床免疫, 12(1):98, 1980.

34) WHO Scientific Group on Immunodeficiency : Immunodeficiency diseases. Clin. Immunol. Im. munopathol., $13: 296,1979$.

35）佐藤 真：胃癌患者の采養評価に関する臨床的研 究一術前栄美状態の計量化による術後合併应発生 予測指数の作成一，日外会誌，83(1)：66，1982.

36）佐藤 真：胃缲患者の術前術後における栄養評価 と免疫能, 衍後代謝研究会誌, 14：209，1980。

37) Neumann, C.G.: Immunologic responses in malnourished children. Am. J. Clin. Nutr., 28 : $89,1975$.

38）矢田健太郎, 中山拓郎, 曾根三郎：がん患者の免疫 学的バラメーター，臨床免疫，13(3)：41，1981.

39）小玉正智, 寺田信國, 橋本 勇：胃癌患者における 各種兔疫学的ハラメーターの検討，臨床免疫， 10(4): 461, 1978 .
40) Wybran, J.: Isolation of normal $T$ cells in chronic lymphatic leukemia. Lancet, 1 : 126, 1973.

41）佐々木睦男：ヒトTリンパ球におけるロゼット 形成能と PHA 反応性の多様性に咸する研究. 弘 前医学, $27: 721,1975$.

42) Thomas, J.W., Coy, P. and Lewis, H.S. : Effect of therapeutic irradiation on lymphocyte transformation in lung cancer. Cancer, 27: 1046 , 1971.

43）木元元治, 静 雅彦, 山田隆成 : 癌白血病における リンパ球の動態に咸する研究(第 1 報)，臨床免疫， $1: 157,1969$.

44) Twomey, P.L. and Catalona, W.J.: Cellular immunity in cured cancer patients. Cancer, 33 : 435, 1974.

45）神代龍之介：リンバ球幼若化能による坦癌宿主低 抗性の評価に関する研究. II. 胃癌, 食道癌患者の リンバ球奻若化能について, 福岡医誌, $67: 339$, 1976.

46) Koperztych, S. and Rezkallah, M.T.: Cellmediated immunity in patients with carcinoma. Correlation between clinical stage and immunocompetence. Cancer, 38: 1149, 1976.

47）小林良彦：リンパ球の subpopulation と幼若化現 象からみた担癌体の自己防蒚能について, 臨床免 疫, $6: 487,1974$.

48）堀井秀夫：胃癌患者末梢血数の検討, 名市大医誌, $14: 102,1963$.

49）折田蒸三：摘脾の畽痬免疫学的意義, 消化器外科, 6(13): 1837, 1983 .

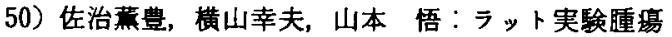
(MRMT-1) における担癌脾摘時の各種免疫賦活 剂の効果，日癌治療誌，17：1168，1982。

51）中神義三，川井 博：尿路性器患者に対する免度 ハシラメータ一と免疫化学療法. 日本外科系連合学 会誌, 5(5)：35, 1980 .

52) Lauren, P.: The two histological main types of gastric carcinoma. Diffuse and so-called intestinal type carcinoma. An attempt at a histological classification. Acta Ptho. et Microbiol. Scandinav., $64: 31,1965$.

53）中村恭一：胃癌の病理一坆小癌と組織発生. 金芳 堂 (京都), 1972. 